\begin{tabular}{l|l|l|l} 
Case Reports in & $\begin{array}{l}\text { Case Rep Neurol 2010;2:32-36 } \\
\text { D0I: 10.1159/000313637 }\end{array}$ & Published online: April 27, 2010 & $\begin{array}{l}\text { @ 2010 S. Karger AG, Basel } \\
\text { ISSN 1662-680X } \\
\text { www.karger.com/crn }\end{array}$ \\
\hline
\end{tabular}

\title{
Spinal Epidural Hematoma as a Complication of Intravenous Thrombolysis in an Acute Ischemic Stroke Patient
}

\author{
Ron Liebkind ${ }^{a} \quad$ Jukka Putaala ${ }^{a}$ Mika Leppä ${ }^{a} \quad$ Jukka Oulab \\ Turgut Tatlisumak ${ }^{a}$ \\ ${ }^{a}$ Department of Neurology and b Helsinki Medical Imaging Center, Helsinki \\ University Central Hospital, Helsinki, Finland
}

\section{Key Words}

Cerebral infarction · Thrombolysis · Spinal epidural hematoma

\begin{abstract}
An 80-year-old white male suffered a stroke, fell to the floor, and suffered acute right hemiparesis and facial palsy. After an intravenous alteplase infusion $2.5 \mathrm{~h}$ later, the patient first complained of numbness in his right arm, then neck pain, followed by left leg numbness and slowly progressing paraparesis. MRI of the spine demonstrated an acute spinal dorsal epidural hematoma extending from the $\mathrm{C} 6$ to the T6 level; $12 \mathrm{~h}$ later, he underwent hematoma evacuation and laminectomy. Three months after surgery, the patient was paraplegic with moderate sensory loss below mamillary level. Acute ischemic stroke is often associated with a sudden fall, which, after thrombolysis, may result in unusual hemorrhagic complications.
\end{abstract}

\section{Introduction}

Currently, the first-line treatment for acute ischemic stroke is intravenous administration of the recombinant tissue plasminogen activator alteplase within $4.5 \mathrm{~h}$ of symptom onset [1]. According to the Cochrane reviews, however, up to $9 \%$ of stroke patients treated with alteplase suffer from symptomatic intracranial hemorrhages ( $\mathrm{ICH}$ ) [2]. Figures for severe extracranial hemorrhages following thrombolysis have ranged from $2-13 \%$ [3]. Despite several events of spontaneous epidural hematoma after thrombolytic treatment of myocardial ischemia with alteplase $[4,5]$, the two descriptions of spinal hematomas following thrombolysis for ischemic stroke have involved patients in Korea and Singapore $[6,7]$. We present what is, to the best of our knowledge, the first Caucasian 


\begin{tabular}{l|l|l|l} 
Cose Reports in & $\begin{array}{l}\text { Case Rep Neurol 2010;2:32-36 } \\
\text { D0I: 10.1159/000313637 }\end{array}$ & Published online: April 27, 2010 & $\begin{array}{l}\text { @ 2010 S. Karger AG, Basel } \\
\text { ISSN 1662-680X } \\
\text { www.karger.com/crn }\end{array}$ \\
\hline
\end{tabular}

patient with spinal epidural hematoma following alteplase administration for acute ischemic stroke.

\section{Case Report}

An 80-year-old man with hypertension and type 2 diabetes mellitus had a sudden fall at home. At sight, he complained of right hemiparesis and was transported to hospital. In the emergency room, his National Institutes of Health Stroke Scale (NIHSS) score was 5, he had a normal level of consciousness, his arterial blood pressure was $157 / 85 \mathrm{~mm} \mathrm{Hg}$, and electrocardiography showed normal sinus rhythm. Neurological examination revealed right hemiparesis with a focus in his right leg, facial palsy of the central type, and mild cervical pain. On the right side, he reacted to pain by flexing both the upper and lower right limbs. After noncontrast brain computed tomography which revealed no abnormalities, the patient received intravenously $66.6 \mathrm{mg}$ of alteplase according to our institutional protocol $2.5 \mathrm{~h}$ from symptom onset. During the infusion, he first complained of numbness in his right arm, then neck pain, followed by left leg numbness. Babinski's sign became positive on the left side. Subsequent brain CT showed no hemorrhage, and CT angiography of the cervical arteries ruled out basilar artery occlusion. Alteplase infusion was completed, resulting in lessened bilateral symptoms in the lower extremities and improvement of facial palsy.

Two hours after the thrombolysis, the patient's NIHSS score was 4. He complained of severe lower cervical pain and slowly progressing paraparesis with decreasing sensation of touch and pinprick below the mamilla. MRI of the spine demonstrated an acute spinal dorsal epidural hematoma extending from the $\mathrm{C} 6$ to the T6 level, compressing the spinal cord (fig. 1). The patient's prothrombin time (23 s), activated partial thromboplastin time (30 s), fibrinogen $(2.0 \mathrm{~g} / \mathrm{l})$, and platelet count $(154 \mathrm{~g} / \mathrm{l})$ all fell within the normal range. Promptly, he received fresh frozen plasma, cyclokaprone, and thrombocytes, and hematoma evacuation and laminectomy took place the next morning, $12 \mathrm{~h}$ after the symptom progression.

Three months after the operation, he was still paraplegic with no movement in his legs, but retaining moderate sensation of touch. At that point, MRI of the spine showed a postoperative lesion with myelopathy, but as expected, no longer any visible hematoma.

\section{Discussion}

Intravenous thrombolysis is the first-line treatment for acute ischemic stroke. According to the Cochrane reviews, $9 \%$ of stroke patients treated with alteplase suffer from symptomatic ICHs [2], and post-treatment, $6.4 \%$ of those receiving any thrombolysis develop ICHs within $36 \mathrm{~h}$ [8]. Risk for spinal hemorrhages has theoretically been associated with intravenous thrombolysis for ischemic stroke, but such complications concern mainly patients with myocardial infarction $[4,5]$. Recently, two Asian patients, following thrombolysis for ischemic stroke, suffered spinal hemorrhages one had a spinal subdural hematoma [6] and the other a spinal epidural hematoma [7]. Thus, spinal hematomas are not only theoretical, but seem to be a rare but clear complication also in stroke patients receiving thrombolytic therapy.

Our patient developed acute right-sided hemiparesis leading to a nonsignificant fall at his home, and following alteplase infusion a spinal epidural hemorrhage developed. In the emergency room - apart from his neurological findings and symptoms - when specifically asked, he also reported mild neck pain. Similarly, in one report of spinal subdural hematoma after thrombolysis for ischemic stroke [6], that patient experienced progressive cervical pain after start of thrombolytic treatment. Spinal epidural hematomas can occur due to trauma, thrombolysis, or even spontaneously, the latter occurring particularly in patients with hematological abnormalities [9]. As the epidural space contains venous plexuses, an anatomical variation or anomaly could also be a predisposing factor for a hemorrhage attributable to thrombolysis. 


\begin{tabular}{l|l|l|l} 
Cose Reports in & Case Rep Neurol 2010;2:32-36 & Published online: April 27, 2010 & $\begin{array}{l}\text { ○ 2010 S. Karger AG, Basel } \\
\text { ISSN 1662-680X } \\
\text { wol: } 10.1159 / 000313637\end{array}$ \\
& & & \\
\hline
\end{tabular}

An important aspect of our report is that stroke patients often experience minor falls at the onset of their symptoms, which may go unnoticed because of their mild appearance. Another notable point presented in the literature is that, following thrombolysis, severe pain attributable to spinal hematoma need not necessarily be located in the spinal areas, but can present even in more remote regions, such as the shoulder [7].

\section{Conclusions}

Acute ischemic stroke often follows a sudden fall - with a possibility of trauma which, in turn, may result in unusual hemorrhagic complications after intravenous thrombolysis. When any stroke patient develops unusual bilateral symptoms or pain, radiological examination of the spine should therefore also be an option.

\section{Acknowledgements}

This work was supported in part by the Helsinki University Central Hospital. 


\begin{tabular}{l|l|l|l} 
Case Reports in & $\begin{array}{l}\text { Case Rep Neurol 2010;2:32-36 } \\
\text { D0I: } 10.1159 / 000313637\end{array}$ & Published online: April 27, 2010 & $\begin{array}{l}\text { @ 2010 S. Karger AG, Basel } \\
\text { ISSN 1662-680X } \\
\text { www.karger.com/crn }\end{array}$ \\
\hline
\end{tabular}

Fig. 1. Magnetic resonance images of the spinal cord sagittal (a) and axial (b). In the fat-saturated T2weighted sagittal image an acute spinal dorsal epidural hematoma is visible, compressing the spinal cord and extending from foramen magnum to Th5 level. The T2-weighted axial image shows the epidural hematoma compressing the spinal cord at the level of C6.
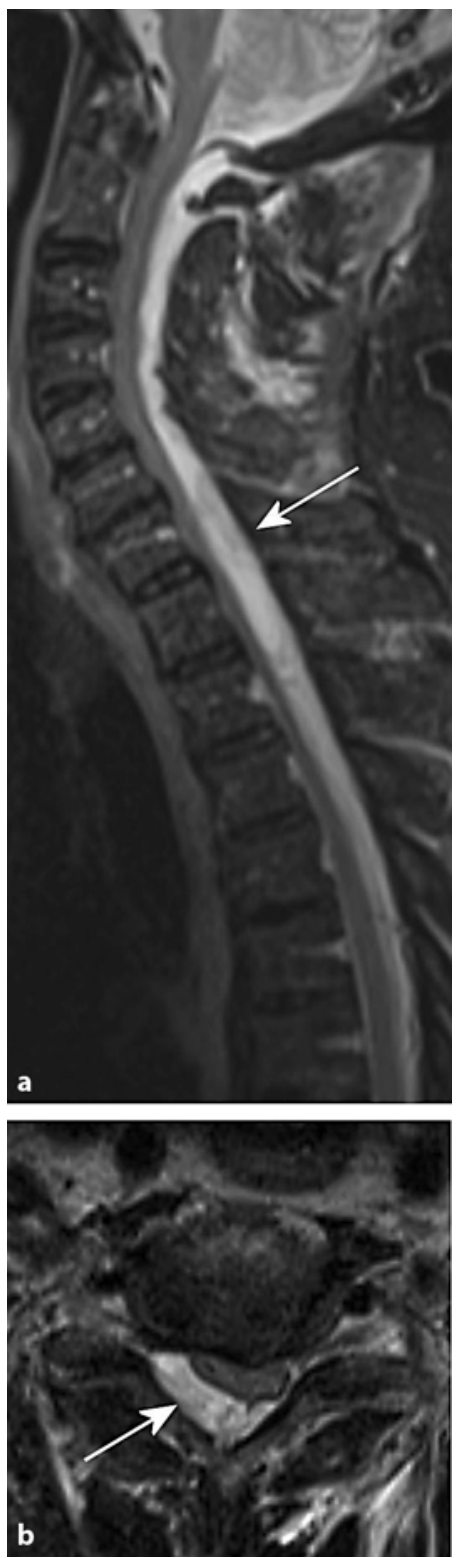


\section{References}

1 Hacke W, Kaste M, Bluhmki E, et al: Thrombolysis with alteplase 3 to $4.5 \mathrm{~h}$ after acute ischemic stroke. N Engl J Med 2008;359:1317-1329.

2 Wardlaw JM, Zoppo G, Yamaguchi T, Berge E: Thrombolysis for acute ischaemic stroke. Cochrane Database Syst Rev 2003;CD000213.

-3 Bravata DM, Kim N, Concato J, Krumholz HM, Brass LM: Thrombolysis for acute stroke in routine clinical practice. Arch Intern Med 2002;162:1994-2001.

-4 Sawin PD, Traynelis VC, Follett KA: Spinal epidural hematoma following coronary thrombolysis with tissue plasminogen activator. Report of two cases. J Neurosurg 1995;83:350-353.

5 Cohen JE, Ginsberg HJ, Emery D, Schwartz ML: Fatal spontaneous spinal epidural hematoma following thrombolysis for myocardial infarction. Surg Neurol 1998;49:520-522; discussion 3.

-6 Kim SH, Choi SH, Song EC, Rha JH, Kim SR, Park HC: Spinal subdural hematoma following tissue plasminogen activator treatment for acute ischemic stroke. J Neurol Sci 2008;273:139-141.

7 Yeo LL, Lim JS, Sharma VK: Spinal epidural hematoma after intravenous thrombolysis for acute ischemic stroke. J Neurol Sci 2009;284:190-191.

-8 Tissue plasminogen activator for acute ischemic stroke: The National Institute of Neurological Disorders and Stroke rt-PA Stroke Study Group. N Engl J Med 1995;333:1581-1587.

9 Groen RJ, Ponssen H: The spontaneous spinal epidural hematoma. A study of the etiology. J Neurol Sci 1990;98:121-138. 